\title{
The Effect of Black Garlic (Allium sativum Linn) on Cardiac and Aortic Histopathology in Experimental Studies in Obesity Rats
}

\author{
Fairuz Azmila Purnomo ${ }^{1}$, Vega Karlowee ${ }^{2}$, Noor Wijayahadi ${ }^{3}$, Andreas Arie Setiawan ${ }^{*}$ \\ ${ }^{1}$ Faculty of Medicine, Universitas Diponegoro, Semarang, Indonesia \\ ${ }^{2}$ Department of Anatomical Pathology, Faculty of Medicine, Universitas Diponegoro, Semarang, Indonesia \\ ${ }^{3}$ Department of Pharmacology and Therapy, Faculty of Medicine, Universitas Diponegoro, Semarang, Indonesia \\ ${ }^{4}$ Departement of Internal Medicine, Faculty of Medicine, Universitas Diponegoro, Semarang, Indonesia
}

\section{Article Info Abstract}

History

Received: 09 July 2021

Accepted: 18 Aug 2021

Available: 31 Aug 2021

\begin{abstract}
Background: Obesity is a disorder or disease characterized by the accumulation of excess fat in the body due to an imbalance of energy intake for a long time. Accumulation of fat can reduce adiponectin, causing cardiac hypertrophy, endothelial vasodilation, and other cardiovascular diseases. Black garlic contains high antioxidants in the form of S-Allylcysteine (SAC), which functions to increase adiponectin.
\end{abstract}

Objective: To determine the effect of Black garlic on the histopathological picture of the heart and aorta of obese rats.

Methods: This study was an experimental study with a randomized post-test only design which control group design composed of 5 groups of male white rats Sprague Dawley (Rattus norvegicus) fed High Fat Fructose Diet (HFFD) enriched with $1.25 \%$ cholesterol and $0.5 \%$ cholic acid for 8 weeks and was given black garlic intervention at doses of $450 \mathrm{mg} / 200 \mathrm{~g} \mathrm{BW}, 900 \mathrm{mg} / 200 \mathrm{~g} \mathrm{BW}$ and $1350 \mathrm{mg} / 200 \mathrm{~g} \mathrm{BW}$ for 4 weeks. Results: Administration of black garlic significantly reduced bodyweight of rats $(\mathrm{p}=0.001)$, and the results did not significantly reduce heart weight $(\mathrm{p}=0.147)$, aortic weight $(\mathrm{p}=0.061)$, histopathological changes in heart wall thickness $(\mathrm{p}=0.423)$ and aortic wall thickness $(\mathrm{p}=0.802)$. The effective doses of black garlic in this study were $450 \mathrm{mg} / 200 \mathrm{~g} \mathrm{BW}, 900 \mathrm{mg} / 200 \mathrm{~g} \mathrm{BW}$ and $1350 \mathrm{mg} / 200 \mathrm{~g} \mathrm{BW}$ of rats. The optimal dose is $900 \mathrm{mg} / 200 \mathrm{~g} \mathrm{BW}$.

Conclusion: Black garlic gave a significant reduction in the bodyweight of rats and no significant reduction in heart weight, aortic weight, cardiac and aortic histopathological features.

Keywords: Black garlic, Obesity, Heart and aortic histopathology Permalink/ DOI: https://doi.org/10.14710/jbtr.v7i2.11686

\section{INTRODUCTION}

Obesity is still a serious problem in Indonesia, based on the results of Indonesia's Basic Health Research (Riskesdas 2018), showing an increased prevalence of the proportion of obesity in adults aged $>18$ years from $14.8 \%$ (2013) to $21.8 \%$ (2018) using indicators Overweight in adults, named Body Mass Index (BMI) $\geq$ 27.0. ${ }^{1}$ In Semarang city, the prevalence of obesity based on BMI category in the population is $23.67 \%$ in men and $34.61 \%$ in women. ${ }^{1}$

Obesity is a disorder or disease characterized by the accumulation of excess body fat as a result of an imbalance in energy intake used for a long time.

* Corresponding author:

E-mail: andreasarie45@gmail.com

(Andreas Arie Setiawan)
The causes of obesity in Indonesia are multifactorial in nature, such as genetic factors, psychological factors, socioeconomic status, low physical activity, unhealthy eating patterns, such as eating fast food (junk food) and sweet drink. Based on Riskesdas data regarding the analysis of the Individual Food Consumption Survey (SKMI) in 2014, 40.7\% of Indonesians consume fatty foods, $53.1 \%$ consume sweet foods, $93.5 \%$ consume less vegetables and fruit; and $26.1 \%$ lack physical activity. ${ }^{2}$

Obesity often causes an increase of fat deposits around the heart and blood vessels. Fat accumulation can increase the presence of adipokines which will produce reactive oxygen species (ROS) and produce a process known as stress oxidative. An increase in ROS and a decrease in antioxidants causes various abnormalities, including endothelial dysfunction, characterized by 
decreased bioavailability of vasodilators, especially nitric oxide and increased contractility of the endothelium and leads to atherosclerosis. ${ }^{3}$ Increased fat deposits around the blood vessels can also cause proinflammatory, pro-fibrotic, and excessive cytokines that can cause inflammation and atherosclerosis, resulting in an increase in thickness of the intima-media and a decrease in arterial elasticity. $3,4,5$

Heart and blood vessel disease are closely related to obesity such as coronary heart disease, heart failure, hypertension, stroke, atrial fibrillation and cardiomyopathy. Obesity-related cardiomyopathy refers to the gradual replacement of the myocardium by irregular bands of adipose tissue, which can lead to atrophy caused by pressure on myocardial cells, the toxic effect of locally produced adipokines in the adjacent myocardium. This fat infiltration can lead to lipotoxicity and increase cardiomyocyte dysfunction. On the histological picture, there is cardiomyocyte hypertrophy, fat infiltration in the myocardium and fibrosis. ${ }^{6,7}$

Garlic (Allium sativum L.) is a plant widely used as a flavoring and as a herbal treatment that has been practiced for years in the world. Garlic contains organosulfur compounds and bioactive enzymes. ${ }^{8,9}$ These compounds can improve and maintain a healthy body. However, the consumption of underground white in food and medicine directly is very limited because of the spicy taste and the tendency to cause stomach upset. ${ }^{10}$ Other alternatives can be done to eliminate this, namely by means of fermentation.

Black garlic is garlic that is processed by heating at controlled temperature and humidity for approximately one month without any additional treatment so that the water content decreases. So that this process makes the garlic turn black, gives a sweet taste and has a chewy consistency. ${ }^{11}$ Black garlic itself has the advantage of fresh garlic, which has stronger antibacterial properties and antioxidants two times higher than ordinary garlic because it contains S-allycysteine (SAC) and S-allylmercapto-cysteine (SAMC).

According to research, black garlic contains high antioxidants, so they can be used in heart protection related to atherosclerosis and increased hyperlipidemia in experimental animals that are induced by a high-fat diet because black garlic has protective properties against the immune system, oxidative stress, and inflammation $^{9,12}$, since they have antioxidants that can ward off free radicals, balance oxidative stress and prevent the formation of reactive oxygen. Based on previous research, researchers are interested in conducting experimental research on the effect of black garlic on the histopathological features of the heart and aorta of obesity experimental animals. This study was conducted on male Sprague Dawley rats to consider ethical reasons for not doing it in humans.

\section{MATERIALS AND METHODS}

This study was conducted at the Laboratory of the Center for Food and Nutrition Studies, Gadjah Mada University, Yogyakarta. The histopathology examination of the heart and aorta of experimental animals was done at the Laboratory of Pathology Anatomy, Faculty of Medicine, Universitas Diponegoro. The black garlic was obtained from the production of research results in biotechnology by the Agency for the Assessment and Application of Technology (BPPT) at the BPPT Tangerang Laboratory. All research activities were carried out in March-August 2020.

This laboratory experiment used a randomized posttest only with a control group design. This experiment used obese Sprague Dawley (Rattus norvegicus) male rats which were given the High Fat Fructose Diet (HFFD) enriched with $1.25 \%$ cholesterol and $0.5 \%$ cholic acid which led to obesity and black garlic. The outcome is a histopathological picture of the heart and aorta of the rats.

The research sample was assigned randomly with a simple randomization method, which met the inclusion and exclusion criteria. The samples used in this study were 30 male Sprague Dawley rats (Rattus norvegicus) aged 8-10 weeks (adults) with a bodyweight of 100-150 grams. Thirty male Sprague Dawley rats that met the inclusion criteria and exclusion were adapted for 7 days in the laboratory inside a single cage and given standard food and drink ad libitum. On day 8, male Sprague Dawley rats were divided into five groups, each consists of 6 randomly selected Sprague Dawley rats. In the control group, normal control were given standard feed for 12 weeks $(\mathrm{N})$. The negative $(\mathrm{KN})$ group was given HFFD feed for 12 weeks, while the treatment groups one, two, and three were given HFFD feed for 8 weeks and continued with standard feed and black garlic intervention for 4 weeks. With stratified doses in each group, namely $450 \mathrm{mg} / 200 \mathrm{~g} \mathrm{BW}$ (P1), $900 \mathrm{mg} / 200 \mathrm{~g}$ $\mathrm{BW}$ (P2), and $1350 \mathrm{mg} / 200 \mathrm{~g} \mathrm{BW}$ (P3) of bodyweight, black garlic were given through the enteral, for food and drink were given ad libitum. After 4 weeks of intervention, the rats were weighed and anesthetized first, and euthanized. Heart and aortic organs were taken, histopathological preparations were made with $\mathrm{HE}$ staining, and observed three different viewpoints with 100 times magnification of the heart, and four different viewpoints were observed magnification of the aorta with light microscopy 400 times and the histopathological changes of the heart and aorta were seen.

The independent variable of this study was the provision of black garlic with stratified doses. The dependent variable in this study was a picture of the histopathological changes of the heart and aorta of the obese male white rat Sprague Dawley (Rattus norvegicus). The obtained data are primary data from the histopathological analysis of the heart and aorta of male Sprague Dawley (Rattus norvegicus) rats from each group. The data were tested for normality by using the Saphiro-Wilk test. The difference between groups was tested using non-parametric Kruskal-Wallis statistics.

This study was reviewed and approved by the Health Research Ethics Commission of the Faculty of Medicine, Diponegoro University with No. 37 / EC / H / KEPK / FKUNDIP / V / 2020.

\section{RESULTS}

Rats' Weight Before and After HFFD Administration

All rats were weighed before being given HFFD after acclimation and after 8 weeks of HFFD. The results are presented in Table 1. 
Table 1.Changes in body weight of rats before and after HFFD administration

\begin{tabular}{ccccc}
\hline Treatment Group & \multicolumn{3}{c}{ Rat's Body Weight (g) } \\
& Before & After & P & $\boldsymbol{\Delta}$ \\
\hline $\mathbf{K}_{\mathbf{T}}$ & $168,66 \pm 3,26$ & $208.83 \pm 3.60^{\text {bcde }}$ & $0,001^{*}$ & $40.16 \pm 0.75^{\text {bde }}$ \\
$\mathbf{K}_{\mathbf{N}}$ & $170,16 \pm 2,56$ & $242.50 \pm 2.25^{\mathrm{a}}$ & $0,001^{*}$ & $72.33 \pm 0.81^{\mathrm{a}}$ \\
$\mathbf{P}_{\mathbf{1}}$ & $171.66 \pm 4,27$ & $244.00 \pm 4.42^{\mathrm{a}}$ & $0,001^{*}$ & $72.33 \pm 0.81^{\mathrm{a}}$ \\
$\mathbf{P}_{\mathbf{2}}$ & $170.16 \pm 2.78$ & $242.33 \pm 2.58^{\mathrm{a}}$ & $0,001^{*}$ & $72.16 \pm 1.16^{\mathrm{a}}$ \\
$\mathbf{P}_{\mathbf{3}}$ & $168.33 \pm 2.80$ & $240.33 \pm 2.42^{\mathrm{a}}$ & $0,001^{*}$ & $72.00 \pm 0.63^{\mathrm{a}}$ \\
\hline $\mathbf{p}^{\mathbf{1}}$ & $\mathbf{0 , 3 9 9}$ & $\mathbf{0 , 0 0 1 *}$ & & $\mathbf{0 , 0 0 1 *}$
\end{tabular}

Rat body weight $=\left(\right.$ mean \pm SD): $n: 6$ rats / group: $p=$ Paired T-test $p^{1}=$ One Way ANOVA test; $a, b, c, d$, e refers to the differences between groups ( $\mathrm{p}<0.05$ ); Normally distributed data were tested for LSD multiple comparisons.

Table 2.Weight Loss Before and After Black Garlic Administration

\begin{tabular}{|c|c|c|c|c|}
\hline \multirow[t]{2}{*}{ Treatment Group } & \multicolumn{4}{|c|}{ Rat's Body Weight (g) } \\
\hline & Before & After & $\mathbf{P}$ & $\Delta$ \\
\hline $\mathbf{K}_{\mathbf{T}}$ & $208 \pm 3,60^{\text {bcde }}$ & $238,16 \pm 4,35^{\text {bcde }}$ & $0,001 *$ & $29,33 \pm 2,25^{\text {bc }}$ \\
\hline $\mathbf{K}_{\mathbf{N}}$ & $242,50 \pm 2,25^{\mathrm{a}}$ & $305,16 \pm 2,56^{\text {acde }}$ & $0,001 *$ & $62,66 \pm 1,63^{\text {acde }}$ \\
\hline $\mathbf{P}_{1}$ & $244 \pm 4,42^{\mathrm{a}}$ & $284,33 \pm 4,63^{\mathrm{abdc}}$ & $0,001 *$ & $40,33 \pm 1,86^{\text {abde }}$ \\
\hline $\mathbf{P}_{2}$ & $242,33 \pm 2,58^{\mathrm{a}}$ & $272,66 \pm 3,14^{\mathrm{abc}}$ & $0,001 *$ & $30,33 \pm 2,73^{\mathrm{bc}}$ \\
\hline $\mathbf{P}_{3}$ & $240,33 \pm 2,42^{\mathrm{a}}$ & $270,66 \pm 3,66^{\mathrm{abc}}$ & $0,001 *$ & $30,33 \pm 1,50^{\mathrm{bc}}$ \\
\hline $\mathbf{p}^{1}$ & 0,001* & 0,001* & & P 0,001x \\
\hline
\end{tabular}

Rat body weight $=\left(\right.$ mean \pm SD): $\mathrm{n}$ : 6 rats / group: $\mathrm{p}=$ Paired T-test $\mathrm{p}^{1}=$ One Way ANOVA test; $\mathrm{a}, \mathrm{b}, \mathrm{c}, \mathrm{d}, \mathrm{e}$ refers to the difference between groups ( $\mathrm{p}<0.05)$; Normally distributed data were tested for LSD multiple comparisons; $\mathrm{x}$ : Kruskall Wallis.

Table 3. Lee's Index of Weight Change

\begin{tabular}{|c|c|c|c|c|}
\hline \multirow{2}{*}{$\begin{array}{c}\text { Treatment } \\
\text { Group }\end{array}$} & \multicolumn{4}{|c|}{ Rat's Body Weight (g) } \\
\hline & Before & After & $\mathbf{P}$ & $\mathbf{A}$ \\
\hline $\mathbf{K}_{\mathbf{T}}$ & $\begin{array}{c}285,79(283,02- \\
289,87)^{\text {bcde }}\end{array}$ & $\begin{array}{c}288.64(283,57- \\
291,61)^{\mathrm{bc}}\end{array}$ & $0,003 *$ & $0.96(0,15-4,32)^{\mathrm{bcde}}$ \\
\hline $\mathbf{K}_{\mathbf{N}}$ & $319.29(311-325)^{\mathrm{a}}$ & $\begin{array}{c}332.53(329,32- \\
338,03)^{\text {acde }}\end{array}$ & $0,003 *$ & $14.63(3,86-22,04)^{\text {acde }}$ \\
\hline $\mathbf{P}_{1}$ & $323.92(311.73-327,67)^{\mathrm{a}}$ & $\begin{array}{c}302.700(294,05- \\
307,65)^{\text {abdc }}\end{array}$ & $0,003 *$ & $-19,31(-22,24--11,58)^{\text {abde }}$ \\
\hline $\mathbf{P}_{2}$ & $319.08(314,48-323,78)^{\mathrm{a}}$ & $\begin{array}{c}286.72(283,54- \\
290,48)^{\mathrm{bc}}\end{array}$ & $0,003 *$ & $-32,17(-33,59--30,51)^{\mathrm{abc}}$ \\
\hline $\mathbf{P}_{3}$ & 319,05 & $\begin{array}{c}283,79(276,61- \\
293,33)^{\mathrm{bc}}\end{array}$ & $0,003 *$ & $-32,61(-41,98--30,97)^{a b c}$ \\
\hline$p^{1}$ & 0,006* & 0,001* & & 0,001* \\
\hline
\end{tabular}

Lee Index $=($ median / min-max $) ; \mathrm{n}=6$ rats / group; $\mathrm{p}=$ Wilcoxon test; $\mathrm{p} 1=$ Kruskal-Wallis test; $\mathrm{a}, \mathrm{b}, \mathrm{c}, \mathrm{d}, \mathrm{e}, \mathrm{f}, \mathrm{g}$ refers to the differences between groups ( $\mathrm{p}<0.05$ ); tested the Mann Whitney multiple comparisons.

Bodyweight of rats (Table 1) before HFFD showed non-significant difference $(\mathrm{p}>0.05)$, but after being given HFFD there was a significant difference in $\mathrm{P}_{1}$ $(\mathrm{p}=0.001), \mathrm{P}_{2}(\mathrm{p}=0.001), \mathrm{P}_{3}(\mathrm{p}=0.001)$ against the normal group.

After 8 weeks of HFFD administration, there was a significant increase and difference in bodyweight in rats between groups before and after being given HFFD (Table $1, p=0.001$ ) because before they were given HFFD, rats were only given standard feed, and after being given HFFD they were given of $35 \%$ carbohydrates, $45 \%$ fat, $177.5 \mathrm{~g} / \mathrm{kg}$ of pork oil, 19.87 $\mathrm{kJ} / \mathrm{g}$ of energy, $172.8 \mathrm{~g} / \mathrm{kg}$ of fructose and $20 \%$ protein. The HFFD is rich in cholic acid and cholesterol, causing obesity, and also Sprague Dawley rats are a model of obesity.

Rat's bodyweight $=($ mean $\pm \mathrm{SD}) ; \mathrm{n}=6$ rats / group; $\mathrm{p}=$ Paired T-test $\mathrm{p}^{1}=$ One Way ANOVA test; $\mathrm{a}, \mathrm{b}, \mathrm{c}, \mathrm{d}$, e refers to the differences between groups $(p<0.05$ ); Normally distributed data were tested for LSD multiple comparisons.

\section{Before and After Black garlic Administration}

After the rats were given HFFD for 8 weeks, they were weighed before and after the intervention of black garlic had been delivered. The results were obtained (Table 2, $\mathrm{p}=0.001$ ), which means that there was a significant difference in bodyweight before and after 
given black garlic. It can be seen from the table above that there were changes that occurred in the KN, P1, P2 and $\mathrm{P} 3$ groups which were given HFFD. It can be seen that the smallest increase was in the $\mathrm{N}$ group which were given standard feed only.

Lee's index before and after black garlic administration

Lee's index is a calculation regarding the criteria for obesity in rats. The Lee index is said to be obese if the Lee index value is $\geq 300$. The Lee index was carried out before and after the black garlic intervention.

Lee's index before and after the intervention was significantly different $(\mathrm{p}<0.05)$. Changes in the Lee index at the end of the intervention in the five groups have differed significantly from the start of the intervention (Table 3, $\mathrm{p}=0.001$ ). Losing weight will lower the score of the Lee Index, so that the anti-obesity effect of the intervention of black garlic at doses of 900 $\mathrm{mg} / 200 \mathrm{~g} \mathrm{BW}$ and $1350 \mathrm{mg} / 200 \mathrm{~g} \mathrm{BW}$ for 4 weeks can be confirmed by the Lee index value.

\section{Heart and Aortic Organ Weight Post-Intervention}

After termination, the heart and aorta were weighed. From the data above, the results obtained (Table $4, \mathrm{p}=$ 0.147 ; Table $5, \mathrm{p}=0.061$ ), which means that there is no significant difference in the weight of the heart and aortic organs in each group, so that the administration of HFFD and the intervention of black garlic has not statistically influenced the weight of the heart organ.

Table 4. Heart Weight

\begin{tabular}{|c|c|}
\hline Treatment Group & Heart Weight \\
\hline $\mathbf{K}_{\mathbf{T}}$ & $\begin{array}{c}0,88 \\
(0,77-1,45)\end{array}$ \\
\hline $\mathbf{K}_{\mathbf{N}}$ & $\begin{array}{c}1,18 \\
(1,07-1,61)\end{array}$ \\
\hline $\mathbf{P}_{1}$ & $\begin{array}{c}1,20 \\
(0,92-1,29)\end{array}$ \\
\hline $\mathbf{P}_{2}$ & $\begin{array}{c}1,04 \\
(0,97-1-30)\end{array}$ \\
\hline $\mathbf{P}_{3}$ & $\begin{array}{c}1,10 \\
(0,95-1,26)\end{array}$ \\
\hline $\mathbf{p}$ & 0,147 \\
\hline
\end{tabular}

Mean heart weight $=($ mean $\pm S D): n=6$ rats / group; $\mathrm{p}=$ Kruskal-Wallis test

Table 5. Aortic Weight

\begin{tabular}{cc}
\hline Treatment Group & Aortic Weight \\
\hline $\mathbf{K}_{\mathbf{T}}$ & 1,09 \\
& $(0,69-1,48)$ \\
$\mathbf{K}_{\mathbf{N}}$ & 1,56 \\
& $(1,24-2,30)$ \\
$\mathbf{P}_{\mathbf{1}}$ & 1,22 \\
& $(0,36-1,68)$ \\
$\mathbf{P}_{\mathbf{2}}$ & 1,25 \\
& $(0,78-1,48)$ \\
$\mathbf{P}_{\mathbf{3}}$ & 0,75 \\
& $(0,44-2,06)$ \\
\hline $\mathbf{p}$ & $\mathbf{0 , 0 6 1}$ \\
\hline
\end{tabular}

Mean aortic weight $=($ mean $\pm S D): n=6$ rats $/$ group; $\mathrm{p}=$ Kruskal-Wallis test.
Histological Interpretation of Heart Wall Thickness

Data on the mean heart wall thickness results (Table 6) obtained the smallest $\mathrm{N}$ thickness of $2717.29 \mu \mathrm{m}$, which was only given standard feed. From the treatment group that experienced the smallest heart wall thickness $\mathrm{P} 2$, which is $2763.05 \mu \mathrm{m}$, given the black garlic intervention dose of $900 \mathrm{mg} / 200 \mathrm{~g} \mathrm{BW}$. The thickest wall is in the $\mathrm{KN}$ group, which is $2914.09 \mu \mathrm{m}$, which is only given HFFD feed.

Table 6. Histopathology of Heart Wall Thickness

\begin{tabular}{cc}
\hline Treatment Group & Average Heart Wall Thickness \\
\hline $\mathbf{K}_{\mathbf{T}}$ & 2717.29 \\
& $(2074.80-2777.63)$ \\
$\mathbf{K}_{\mathbf{N}}$ & 2914.09 \\
& $(2474.88-3798.93)$ \\
$\mathbf{P}_{\mathbf{1}}$ & 2921.59 \\
$\mathbf{P}_{\mathbf{2}}$ & $(2302.26-3163.87)$ \\
$\mathbf{P}_{\mathbf{3}}$ & 2763.05 \\
& $(2375.37-3272.27)$ \\
$\mathbf{p}$ & 2904.75 \\
\hline Mean heart thickness $=($ mean \pm SD): $\mathrm{n}=6$ rats / group; \\
$\mathrm{p}=$ Kruskal-Wallis test
\end{tabular}

Table 7. Aortic Wall Thickness

\begin{tabular}{|c|c|}
\hline Treatment Group & Heart Wall Thickness \\
\hline $\mathbf{K}_{\mathbf{T}}$ & $\begin{array}{c}157.38 \\
(108.28-417.64)\end{array}$ \\
\hline $\mathbf{K}_{\mathbf{N}}$ & $\begin{array}{c}139.54 \\
(0.00-186.19)\end{array}$ \\
\hline $\mathbf{P}_{1}$ & $\begin{array}{c}147.60 \\
(62.39-290.26)\end{array}$ \\
\hline $\mathbf{P}_{2}$ & $\begin{array}{c}135.29 \\
(99.85-166.23)\end{array}$ \\
\hline $\mathbf{P}_{3}$ & $\begin{array}{c}148.27 \\
(114.01-179.20) \\
\end{array}$ \\
\hline $\mathbf{p}$ & 0.802 \\
\hline
\end{tabular}

Mean aortic thickness $=($ mean $\pm S D): n=6$ rats $/$ group; $\mathrm{P}=$ Kruskal-Wallis test

From the data above (Table 6), $\mathrm{p}=0.423$, which means that there is no significant difference in the thickness of the heart wall in each group. The provision of black garlic did not statistically affect the histopathology of heart thickness.

\section{Histopathological Interpretation of Aortic Wall Thickness}

The mean data of the results (Table 7) show that the thinnest aortic wall was obtained in P2 group with 135.29 $\mu \mathrm{m}$, and the thickest wall was in $\mathrm{KN}$ group $(139.54 \mu \mathrm{m})$, which was only given HFFD feed.

From the data above, the results $\mathrm{p}=0.802$ (Table 7), which means that there is no significant difference in the thickness of the aortic wall for each group. The provision of black garlic did not statistically affect the histopathology of aortic thickness.

\section{DISCUSSION}

The rats that were given the HFFD feed experienced an increase in bodyweight compared to those given the 
standard feed. This increase was due to feeding HFFD consist of $35 \%$ carbohydrates, $45 \%$ fat, $177.5 \mathrm{~g} / \mathrm{kg}$ of pork oil, $19.87 \mathrm{~kJ} / \mathrm{g}$ of energy, $172.8 \mathrm{~g} / \mathrm{kg}$ of fructose and $20 \%$ protein which are rich in cholic acid and cholesterol, causing obesity.
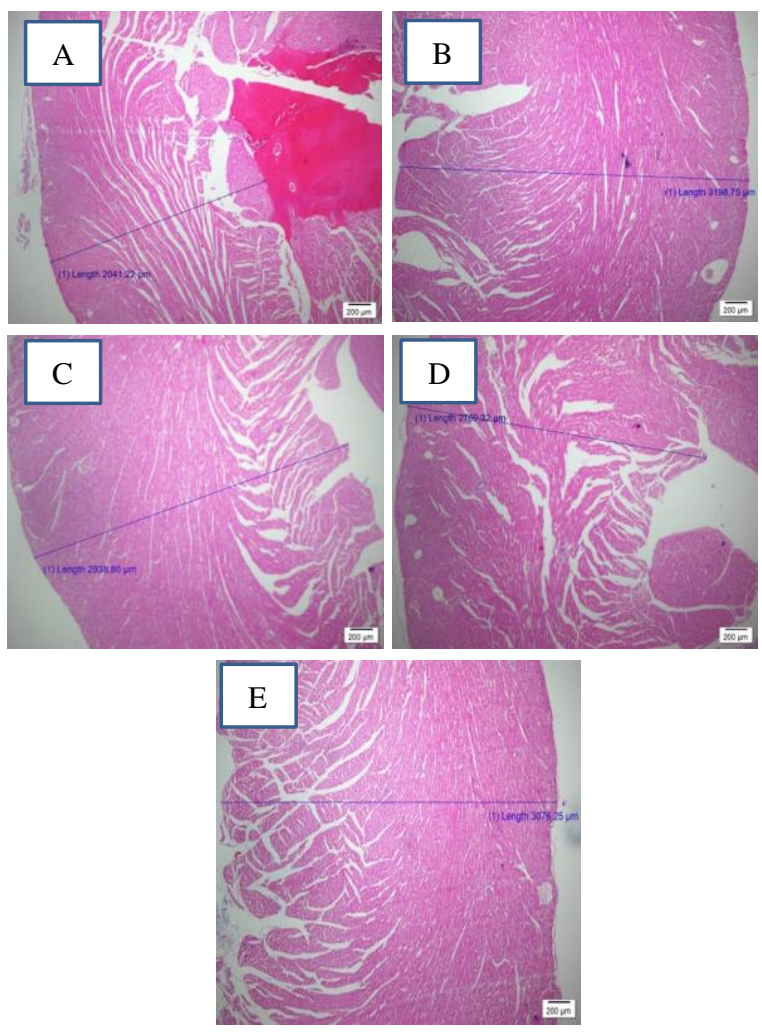

Figure 1. (A) Histopathology of heart wall thickness in the group of rats given standard feed (B) Heart wall thickness in the group of rats fed HFFD (CE) Heart wall thickness in rats given HFFD feed with black garlic intervention 450mg / 200 grams BW, 900mg / 200 grams BW, and 1350mg / 200 grams BW. Hearts were stained with hematoxylin and eosin $(\mathbf{H} \& \mathbf{E}, \mathbf{1 0 0 X})$

In the bodyweight of rats, there was a significant reduction between the normal control group against the negative control group, the normal group to the treatment group, the negative group to the treatment group. The results of this study are consistent with the research of Amor et al, that the weight loss of rats was caused by a decrease in lipid uptake and a decrease in brown adipose tissue, but in this study the measurement was not carried out. ${ }^{13}$ In addition, black garlic have the ability to increase adiponectin, reduce leptin and insulin concentrations. According to $\mathrm{Ha} \mathrm{AW}$ et al, black garlic is able to reduce insulin resistance. ${ }^{14}$ According to Ma W et al, previously increased adiponectin can reduce bodyweight by stimulating glucose utilization and peripheral fatty acid oxidation and also influencing energy expenditure by targeting the central nervous system and increasing oxygen consumption and thermogenesis. ${ }^{15}$ In addition, an increase in adiponectin shows a strong association with an increase in HDL cholesterol and a decrease in LDL cholesterol. ${ }^{15}$ In obesity, there is an increase in leptin so that it experiences leptin resistance and experiences satiety disorders, with black garlic can reduce leptin concentrations, thereby increasing leptin sensitivity where leptin acts on the CNS for weight loss, by
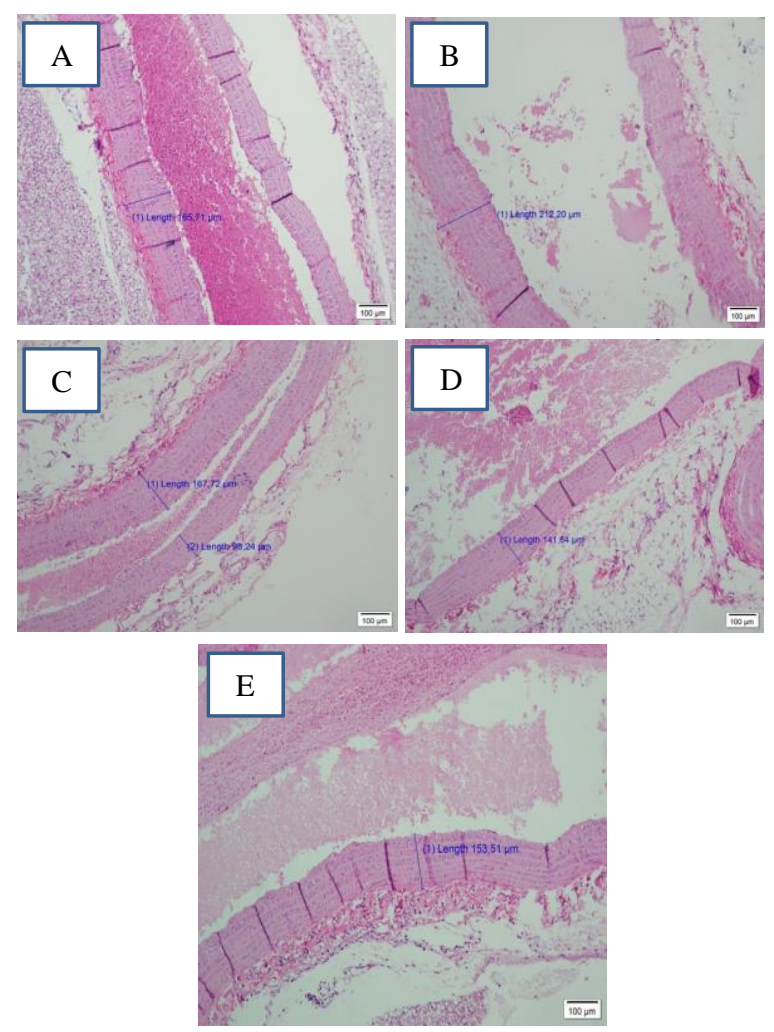

Figure 2. (A) Histopathology of aortic wall thickness in the group of rats given standard feed (B) thickness of the aortic wall in the group of rats given HFFD feed (C) The thickness of the aortic wall in rats given HFFD feed with black garlic intervention 450mg / 200 grams BB, 900mg / 200 grams BW, and $1350 \mathrm{mg} / 200$ grams BW. Aortic were stained with hematoxylin and eosin $(\mathbf{H \& E}, \mathbf{1 0 0 X})$.

decreasing food intake, increasing thermogenesis and increasing energy use. ${ }^{16}$

In the bodyweight of rats in the treatment group with a dose of black garlic $900 \mathrm{mg}$ to black garlic at a dose of $1350 \mathrm{mg}$, there was no significant difference in weight loss of the rats. This suggests that the addition of the dose $1350 \mathrm{mg}$ has no significant results. In the weight of the heart and aortic organs, results were not significant, it was also proven in the study of Amor, et al. cause a decrease in the weight of the heart and aorta organs.

The histopathological examination results of the heart organ which assessed the thickness of the heart wall, showed that the control and treatment groups of rats did not experience any significant changes. This is consistent with the study of Amor et al, that rats given HFFD for 12 weeks were not yet able to cause significant heart and vascular damage. ${ }^{17}$ This could occur due to the lack of time given HFFD to cause damage to the heart. However, administration of HFFD in the study of Mellor et al. was associated with an increase in ROS in the myocardium. ${ }^{18}$ The imbalance between ROS and antioxidants could potentially make the heart vulnerable to oxidative damage and oxidative stress, which can lead to heart pathology. The results showed that the average heart wall thickness of the normal control group was $2717.29 \mu \mathrm{m}$, and the treatment group had a smaller heart wall thickness in the P1 group $2921.59 \mu \mathrm{m}, \mathrm{P} 2$ group of $2763.05 \mu \mathrm{m}$ is lower than the negative control group $2904.75 \mu \mathrm{m}$, and P3 group of $2904.75 \mu \mathrm{m}$ which also decreased but higher than P1. This can be caused by black 
garlic which has organosulfur SAC compounds which can increase adiponectin. ${ }^{19,20}$ Increased adiponectin can have an anti-inflammatory effect and prevent ischemic reperfusion injury through its ability to suppress myocardial inflammation, besides adiponectin has an anti-hypertrophic effect on the heart. ${ }^{21}$ In addition, in rats with narrowed aorta, adiponectin deficiency can cause left ventricular hypertrophy. ${ }^{21}$ Not only that, black garlic contains flavonoids, which are antioxidants that can increase insulin sensitivity and fight ROS. ROS derived from NADPH oxidase activity can cause the release of $\mathrm{NOS}_{3}$ and activate xanthine oxidase. Thus, the NADPH oxidase can serve as the main source for ROS assembly amplification. ROS produced by NADPH oxidase plays a role in the occurrence of angiotensin II-induced cardiac hypertrophy, thereby reducing the thickness of the heart wall or hypertrophy. ${ }^{22}$ In addition, black garlic contains high organosulfur content such as SAC, which can reduce the accumulation of ROS. ${ }^{14}$

The histopathological examination of aortic wall thickness showed that the control and treatment groups of rats did not experience any significant changes. According to Yoo et al, giving high fructose diet can increase the thickness of the aortic wall and decrease the expression of eNOS mRNA. ${ }^{23}$ The average aortic wall thickness of the normal control group is $157.38 \mu \mathrm{m}$, negative control group $139.54 \mu \mathrm{m}, \mathrm{P} 1147.60 \mu \mathrm{m}, \mathrm{P} 2$ $135.29 \mu \mathrm{m}$, and P3 $148.27 \mu \mathrm{m}$. The data showed that rats given black garlic at a dose of $450 \mathrm{mg}, 900 \mathrm{mg}, 1350 \mathrm{mg}$ had decreased aortic wall thickness compared to rats given HFFD only. The biggest decrease occurred in giving black garlic at a dose of $900 \mathrm{mg} / 200 \mathrm{~g} \mathrm{BW}$. This is in accordance with the research of Amor et al, that black garlic contains high SAC and allin, so that they can protect the metabolic and vascular effects that originate from an increase in adiponectin. It is known that adiponectin provides anti-inflammatory effects and prevents endothelial vasodilation, as well as reduces the occurrence of atheroseclerosis. ${ }^{21}$ According to Garcia et al, black garlics increase the production of nitric oxide which significantly increases the expression of the eNOS gene. ${ }^{9}$ eNOS functions to maintain normal blood flow and pressure. In addition, it prevents undesirable conditions such as increased atherogenesis and hypertension. Endothelium function is influenced by ROS which can inactivate nitric oxide, causing vasomotor dysfunction and smooth muscle proliferation, as well as expression of inflammatory genes that cause vasodilation in the endothelium, which is the beginning of the development of atherosclerosis, hypertension and coronary heart disease.

This study has several limitations, including the researchers did not perform blood chemistry tests, antioxidant reserves, limited time to administer HFFD and black garlic to assess more significant effect of black garlic on obese rats, there were differences in the processing of black garlic among other researchers.

\section{CONCLUSIONS}

This study showed that the administration of black garlics decreased histopathological changes in heart wall and aortic wall thickness, but it is not statistically significant. Further studies is needed to observe the effect of black garlic in obese rats with a longer time to obtain significant results, and it is desirable to observe laboratory results, especially inflammatory and metabolic markers.

\section{ACKNOWLEDGEMENTS}

We would like to show our gratitude to our faculty, for their trust and support to this study, to Laboratory of the Center for Food and Nutrition Studies, Gadjah Mada University, Yogyakarta and Laboratory of Pathology Anatomy, Faculty of Medicine, Universitas Diponegoro, Semarang Indonesia, that greatly assisted the research.

\section{REFERENCES}

1. Riset Kesehatan Dasar. Laporan Provinsi Jawa Tengah Riskesdas 2018. Kementerian Kesehatan RI , Hal 119-120. 2018. 119 p.

2. Kementrian Kesehatan Republik Indonesia. Panduan Pelaksanaan Gerakan Nusantara Tekan Angka Obesitas. 2017. p. 32.

3. Fernández-Sánchez A, Madrigal-Santillán E, Bautista M, Esquivel-Soto J, Morales-González Á, EsquivelChirino $\mathrm{C}$, et al. Inflammation, oxidative stress, and obesity. Int J Mol Sci. 2011;12(5):3117-32. doi: 10.3390/ijms 12053117

4. Barbosa JAA, Rodrigues AB, Mota CCC, Barbosa MM, Silva ACSE. Cardiovascular dysfunction in obesity and new diagnostic imaging techniques: The role of noninvasive image methods. Vasc Health Risk Manag. 2011;7(1):287-95. doi: 10.2147/VHRM.S17801

5. Lovren F, Teoh H, Verma S. Obesity and atherosclerosis: mechanistic insights. Can J Cardiol. 2015;31(2):177-83. doi: 10.1016/j.cjca.2014.11.031

6. Haberka M, Skilton M, Biedroń M, Szóstak-Janiak K, Partyka M, Matla M, et al. Obesity, visceral adiposity and carotid atherosclerosis. J Diabetes Complications. 2019;33(4):302-6. doi: 10.1016/j.jdiacomp.2019.01.002

7. Koliaki C, Liatis S, Kokkinos A. Obesity and cardiovascular disease: revisiting an old relationship. Metabolism. 2019;92:98-107. doi: 10.1016/j.metabol.2018.10.011

8. Kang OJ. Physicochemical characteristics of black garlic after different thermal processing steps. Prev Nutr Food Sci. 2016;21(4):348-54. doi: 10.3746/pnf.2016.21.4.348

9. García-Villalón AL, Amor S, Monge L, Fernández N, Prodanov M, Muñoz M, et al. In vitro studies of an aged black garlic extract enriched in S-allylcysteine and polyphenols with cardioprotective effects. J Funct Foods. 2016;27:189-200. doi: 10.1016/j.jff.2016.08.062

10. Oktari K, Azizah Z, Chandra B, Asra R. A review: antioxidant and immunomodulator effects of black garlic. EAS J Pharm Pharmacol. 2020;2(6):193-8. doi: 10.36349/EASJPP.2020.V02I06.001

11. Kimura S, Tung YC, Pan MH, Su NW, Lai YJ, Cheng KC. Black garlic: A critical review of its production, bioactivity, and application. J Food Drug Anal. 2017;25(1):62-70. doi: 10.1016/j.jfda.2016.11.003

12.Chang WT, Shiau DK, Cheng MC, Tseng CY, Chen $\mathrm{CS}, \mathrm{Wu} \mathrm{MF}$, et al. Black garlic ameliorates obesity induced by a high-fat diet in rats. J Food Nutr Res. 2017;5(10):736-41. doi: 10.12691/jfnr-5-10-3 
13. Amor S, González-Hedström D, Martín-Carro B, Inarejos-García AM, Almodóvar P, Prodanov M, et al. Beneficial effects of an aged black garlic extract in the metabolic and vascular alterations induced by a high fat/sucrose diet in male rats. Nutrients. 2019;11(1). doi: 10.3390/nu11010153

14. Ha AW, Kim WK. Antioxidant mechanism of black garlic extract involving nuclear factor erythroid 2like factor 2 pathway. Nutr Res Pract. 2017;11(3):206-13. doi: 10.4162/nrp.2017.11.3.206

15. Ma W, Huang T, Zheng Y, Wang M, Bray GA, Sacks FM, et al. Weight-loss diets, adiponectin, and changes in cardiometabolic risk in the 2-year pounds lost trial. J Clin Endocrinol Metab. 2016;101(6):2415-22. doi: 10.1210/jc.2016-1207

16. Cahyaningrum A. Leptin sebagai indikator obesitas. J Kesehat Prima. 2015;I(1):1364-71. doi: 10.32807/jkp.v9i1.58

17. Carroll JF, Zenebe WJ, Strange TB. Cardiovascular function in a rat model of diet-induced obesity. Hypertension. 2006;48(1):65-72. doi: 10.1161/01.HYP.0000224147.01024.77

18. Mellor K, Ritchie RH, Meredith G, Woodman OL, Morris MJ, Delbridge LMD. High-fructose diet elevates myocardial superoxide generation in mice in the absence of cardiac hypertrophy. Nutrition. 2010;26(7-8):842-8. doi: 10.1016/j.nut.2009.08.017
19. Ha AW, Ying T, Kim WK. The effects of black garlic (Allium satvium) extracts on lipid metabolism in rats fed a high fat diet. Nutr Res Pract. 2015;9(1):30-6. doi: 10.4162/nrp.2015.9.1.30

20. Botas J, Fernandes Â, Barros L, Alves MJ, Carvalho AM, Ferreira ICFR. A comparative study of black and white Allium sativum L.: nutritional composition and bioactive properties. Molecules. 2019;24(11). doi: 10.3390/molecules24112194

21. Aprahamian TR, Sam F. Adiponectin in cardiovascular inflammation and obesity. Int J Inflam. 2011;2011:1-8. doi: 10.4061/2011/376909

22. Takimoto E, Kass DA. Role of oxidative stress in cardiac hypertrophy and remodeling. Hypertension. 2007;49(2):241-8. 10.1161/01.HYP.0000254415.31362.a7

23. Yoo SY, Ahn H, Park YK. High dietary fructose intake on cardiovascular disease related parameters in growing rats. Nutrients. 2017;9(1). doi: 10.3390/nu9010011 